ARTIGOS

\title{
O debate entre Paganismo e Cristianismo em duas obras de Kierkegaard: contribuições para uma reflexão sobre os processos de subjetivação
}

\section{The debate between Paganism and Christianism in two works by Kierkegaard: contributions to a reflection about the processes of subjectivation}

\section{Cristine Monteiro Mattar*}

Universidade Federal Fluminense - UFF, Niterói, Rio de Janeiro, Brasil

\begin{abstract}
RESUMO
O artigo apresenta o debate entre paganismo e cristianismo a partir de duas obras kierkegaardianas: Migalhas Filosóficas ou um bocadinho de filosofia assinada por Johannes Climacus e Doença Mortal, assinada por Johannes AntiClimacus. A primeira mostra a diferença entre a mestria socrática e a mestria cristã, defendendo a superioridade da última. Refere-se "ao deus" que se subentende ser o próprio Cristo, um mestre diferente que não apenas pretende levar o discípulo à reflexão, mas, também, à transformação decisiva de si mesmo. Na segunda, Anti-Climacus descreve o paganismo como desespero. Embora admitindo a superioridade do paganismo em relação à cristandade e ainda que Doença Mortal postule que seria muito útil retomar o espírito grego e começar por ele em meio à farsa do cristianismo paganizado, em ambas a superioridade do ideal cristão se destaca. Tais temáticas são trazidas para uma reflexão sobre os modos de subjetivação valorizados em tempos de preocupações pagãs.

Palavras-chave: Paganismo, Cristianismo, Kierkegaard, Processos de subjetivação.
\end{abstract}

\begin{abstract}
The article presentes the debate between Paganismo and Christianism departing from two kierkegaardian works: Philosophical Fragments, signed by Johannes Climacus and Sickness Unto Death, signed by Johannes AntiClimacus. The first one shows the difference between the socratic and the Christian mastership, defending the superiority of the latter. It refers "to the god" that is understood as Christ himself, a diferente máster who does not only intend to take the disciple to reflection, but also the decisive transformation of his own self; in the second, Anti-Climacus describes paganismo as desperation. Even though he admits the superiority of paganism in relation to Christianity and even though Sickness Unto Death preaches that it would be very useful to return to the Greek spirit and start from it in the middle of the farce of paganized Christianism, in both the superiority of the Christian ideal stands out. Such themes are brought to reflection about the modes of subjectivation valued
\end{abstract}

ISSN 1808-4281

\begin{tabular}{|l|l|l|l|l|l|} 
Estudos e Pesquisas em Psicologia & Rio de Janeiro & v. 12 & n. 3 & p. 792-816 & 2012 \\
\hline
\end{tabular}


in times of pagan worries.

Keywords: Paganism, Christianism, Kierkegaard, Processes of subjetivation.

\section{Introdução}

Embora a presença da filosofia antiga seja constante no pensamento e nas obras do filósofo dinamarquês Sören Kierkegaard, um de seus aspectos é o de servir como contraponto entre socratismo ${ }^{1}$ e cristianismo e entre paganismo e cristianismo, destacando-se este último como o ideal mais alto.

A negatividade infinita da ironia inspirada em Sócrates atuará, na obra kierkegaardiana, no sentido de promover a ignorância socrática no seio da cristandade, mas não para permanecer nela, e sim para que se possa, e principalmente se queira, assumir em seguida uma posição cristã. A ironia desconstruiria as falsas profissões de fé da cristandade, a fim de abrir espaço para a decisão efetiva de agir como cristão, ou ao menos para o reconhecimento de que não se é cristão. Se Sócrates afirmou saber somente que nada sabia, pode-se dizer que Kierkegaard inicia afirmando: só sei que não sou cristão.

Em Migalhas Filosóficas (1844/2008), Johannes Climacus diferencia o mestre socrático do mestre cristão. Já em $O$ Desespero Humano (1849/2002), Anti-Climacus define duas éticas, pagã e cristã, e relaciona o paganismo ao desespero. As duas obras são analisadas a seguir. Embora distanciadas no tempo, ambas nos parecem bastante atuais para uma reflexão sobre um tema de interesse contemporâneo, os chamados processos ou modos de subjetivação, expressão que tomamos emprestada da obra do filósofo francês Michel Foucault (19261984). Tal expressão pode ser entendida como "as formas e as modalidades da relação consigo através das quais o indivíduo se constitui e se reconhece como sujeito" (FOUCAULT, 1984, p. 11). Embora as diferenças importantes entre os dois filósofos, Kierkegaard e Foucault, pode-se afirmar que ambos colocam em questão a noção de subjetividade definida a priori como fundamento universal e essencial a todos os homens (MATTAR, 2011). Nesta direção, pode-se estabelecer um diálogo entre a definição dos modos de subjetivação foucaultiana e a descrição do eu e das personificações do desespero empreendida por Anti-Climacus na obra $O$ Desespero Humano, bem como vislumbrar nos modos de ser descritos como pagão ou cristão modos de constituir-se e reconhecer-se. O eu, na perspectiva kierkegaardiana, é uma relação que não se estabelece com nada de alheio a si, apenas consigo, ou melhor, é a consciência que se tem dessa relação; o eu é o reconhecimento de si 
mesmo, de sua existência concreta e singular, um si mesmo que é uma síntese dos paradoxos da existência, necessários e possíveis, temporal e eterno, finito e infinito, bem diferente das concepções psicológicas de um psiquismo encapsulado que possuiria um funcionamento analisável. Lançado por um Autor e ao mesmo tempo fadado a escolher-se, o eu se constitui na tensão constituído-constituinte em todos os instantes de sua existência. Não podendo livrar-se de quem é, pois não se constitui de forma autônoma, pode, no entanto, "dar resistência aos seus ângulos ao invés de limá-los" (KIERKEGAARD, 1849/2002, p. 37), agindo de forma mais própria ao invés de querer simplesmente assemelhar-se aos outros ou ser um eu de sua exclusiva invenção, que são formas do desespero. Ora, a genealogia foucaultiana visa, sobretudo, alertar para o fato de que, embora possa estar fortemente constituído pelos esquemas prontos que encontra no mundo, é sempre possível ao sujeito participar de forma mais ativa da própria constituição, agindo com maior liberdade. Isto indica que, na visão foucaultiana, ao contrário do modo como se costuma interpretar o pensamento do filósofo francês, não estamos irremediavelmente constituídos pela cultura, uma vez que participamos de tal constituição, seja aceitando passivamente modos de ser considerados normais e adequados em cada época, seja recusando ou resistindo aos mesmos. A tarefa filosófica de lançar um grito de alerta e tornar os sujeitos atentos ao próprio existir nos parece ter sido assumida pelos dois pensadores, sendo a ênfase do presente artigo o pensamento kierkegaardiano.

\section{Migalhas Filosóficas}

Em Migalhas filosóficas ou um bocadinho de filosofia de Johannes Climacus (1844/2008), a ironia em relação aos grandes sistemas filosóficos e à filosofia especulativa principia na escolha do título. Pretende ultrapassar o mestre socrático, aquele que interroga, propondo em seu lugar um mestre diferente, aquele que é capaz de oferecer a vida pelo discípulo; vai além da interrogação filosófica mediante o posicionamento cristão; propõe que a dúvida inicial dê lugar à fé e substitui a ignorância pela vontade como fator decisivo para a ação. Portanto, a diferença entre a mestria socrática e a mestria cristã, embora não definida diretamente nestes termos, é apresentada nesta obra.

O texto, segundo Valls (2000), procura

[...] traduzir em linguagem filosófica de cunho grego o 
escândalo e a loucura da novidade paradoxal de um DeusHomem, que daria um valor absoluto para o instante, supondo que a idéia de um 'kairós', instante da graça, desenvolvida de modo hipotético e por contraste com o chamado projeto socrático, exige uma atitude mental e existencial radicalmente nova $[\ldots]$. (VALLS, 2000, p. 5).

De acordo com Vergote, a obra estava "destinada a estabelecer as determinações da cristicidade referida a Cristo, como conceito simétrico e inverso do conceito de ironia referido a Sócrates [...]" (VERGOTE, 2001, p. 62).

O autor das Migalhas Filosóficas, com efeito, opõe precisamente ao mestre socrático, que é para os seus discípulos apenas a ocasião de relembrar uma verdade desde sempre possuída, o deus 'como mestre e salvador', que é o único que pode introduzir no tempo, pelo evento histórico de sua encarnação paradoxal, da qual todo discípulo precisa tornar-se contemporâneo, uma verdade 'que não poderia ter brotado por si mesma do coração do homem' (VERGOTE, 2001, p. 56).

Johannes Climacus assina a obra. Climacus teve existência real, viveu no ano 600 d.C., foi monge do Mosteiro do Monte Sinai e autor místico. Escreveu Scala Paradisi, texto de ascetismo místico que significa "subida ao paraíso". Em Doença mortal, de 1849, e Exercício do Cristianismo, de 1850, Kierkegaard usará o pseudônimo Johannes Anti-Climacus, que seria cristão, ao contrário de Johannes Climacus $^{2}$, que reconhece não o ser (PAULA, 2009). Vale também lembrar que Climacus declara-se nãocristão no interior da cristandade ocidental e do que identifica como a síntese de cristianismo e filosofia operada por Hegel.

Para Climacus, a filosofia antiga é melhor do que a filosofia sistemática moderna. Afinal, no seu nascedouro, tal filosofia parece ainda não estar contaminada com tantas impurezas. Além disso, nos seus primórdios, a filosofia era mais abrangente e com menor carga intelectiva ou meramente especulativa. Em outros termos, a filosofia tinha maior ligação com a existência humana (PAULA, 2009, p. 87).

Segundo Valls (1844/2008), o problema das Migalhas é formulado a partir de um texto de Lessing, autor alemão que faz a distinção entre dois tipos de verdades: as contingentes ou de fato, que são históricas, e as verdades necessárias ou lógicas, baseadas no princípio da nãocontradição. A dúvida de Climacus refere-se a como basear sua felicidade eterna em verdades históricas, que não possuem necessidade lógica.

As verdades do Cristianismo, que Climacus apresenta como se fossem 
um paradigma inventado por ele, pertencem às verdades históricas, o que coloca, para os pensadores formados no modo racionalista, um abismo que só poderia ser transposto por um "salto".

Propondo um experimento teórico que vá além do socrático, Climacus formula a pergunta: "Em que medida pode-se aprender a verdade?" (KIERKEGAARD, 1844/2008, p. 27) - decorrente da interrogação socrática acerca da virtude. Se a verdade deve ser aprendida, pressupõe-se que não estava presente e deve ser procurada, dificuldade para a qual Sócrates chamou a atenção, denominando-a "proposição polêmica": "[...] é impossível a um homem procurar o que sabe e igualmente impossível procurar o que não sabe, pois o que sabe, não pode procurar porque sabe, e aquilo que não sabe não pode procurar porque não sabe nem ao menos o que deve procurar." (idem, p. 27-28). De acordo com Climacus, Sócrates teria resolvido essa dificuldade alegando que todo aprender e procurar é sempre um recordar - o ignorante necessita apenas lembrar-se para tomar consciência daquilo que sabe. Tal ideia se torna o pathos grego, uma prova da imortalidade da alma, da sua preexistência. É preciso ressaltar aqui que a referência a Sócrates o situa em contornos diferentes, dependendo da obra na qual sua figura é trazida por Kierkegaard. Em Migalhas ele aparece como o mestre reflexivo de ocasião, em contraste com o deus cujo encontro é decisivo e transformador. Já em O Desespero Humano, Sócrates surge como o mais alto expoente da ética grega, superior à cristandade. Em ambas é o homem pagão, diferente do irônico da tese kierkegaardiana sobre o conceito de ironia. (KIERKEGAARD, 1841/2006). Na obra aqui em apreço, Climacus discorda da tese socrática da reminiscência ${ }^{3}$, e propõe que as coisas sejam colocadas de outra maneira, voltando-se antes para os três aspectos da concepção socrática: o estado anterior, o mestre e o discípulo. No argumento socrático, o discípulo se encontra de posse da verdade desde sempre, embora dela não se recorde. Será preciso despertar nele a reminiscência, através da interrogação bastará uma ocasião favorável, alguém que o interrogue corretamente, e a recordação virá. $O$ instante perde, com isso, sua significação decisiva como divisor de águas na vida do sujeito: ele permanecerá onde já estava, só que agora consciente da verdade que trazia em si. Portanto, segundo Climacus, na perspectiva socrática, o estado anterior do discípulo é o da posse da verdade, o mestre é apenas a ocasião e o discípulo não se modifica essencialmente, porque apenas assume o que já era seu.

$\mathrm{Na}$ perspectiva diferente apresentada por Climacus, o estado anterior em que se encontra o discípulo é o da não-verdade, porque a verdade não está no homem e sim em Deus, sendo ademais necessário que o 
homem tome consciência de que está na não-verdade.

O discípulo precisa ter contato com a verdade que está fora dele, e o instante em que isto ocorre é decisivo para toda a sua vida ulterior. O instante nunca volta igual, daí a significação de cada um deles ser decisiva. Em acréscimo, Climacus define o mestre não mais como aquele que apenas interroga, mas como o deus ${ }^{4}$ encarnado - a própria verdade eterna na figura de um homem temporal que é, ao mesmo tempo, a verdade e a condição para atingir a verdade. É o contato com esse deus encarnado que propicia ao discípulo a possibilidade de sair do erro no qual vivera até então - não por ignorância ou esquecimento, mas por uma decisão da vontade.

Apesar de breve e temporal, o instante é decisivo, pleno de eternidade, "plenitude dos tempos" (ibidem, p. 38), visto que o discípulo se torna, a partir do contato com o deus, um homem novo. No instante, o homem torna-se consciente de que nasceu, pois seu estado anterior era o de não-ser. A partir daí não apenas vive, como se fosse uma espécie a mais: passa a existir.

Em um ensaio poético, parte de Migalhas Filosóficas, Climacus refere-se ao deus como mestre e salvador. No caso de Sócrates, a relação era de homem a homem: o discípulo era a ocasião para que o mestre compreendesse a si mesmo, e o mestre para que o discípulo compreendesse a si mesmo. Porém, o deus não precisa de discípulo para compreender a si mesmo: apresenta-se não por necessidade, mas por amor. Dispõe-se a ir até onde está o discípulo, torna-se próximo a ele e chega a colocar-se como seu servo. Procura passar despercebido, estar próximo sem ser visto. O mestre, portanto não será o que apenas ensina ou interroga sobre a verdade, mas o que a vive.

Dentro da "ficção poética" proposta por Climacus, o deus se apresenta como mestre em forma de servo. Se a relação fosse apenas de homem a homem, o que teríamos de mais alto e verdadeiro seria a relação socrática; mas depois que o deus veio pessoalmente, obtivemos o instante e o paradoxo, que é o fato de que um instante histórico, o encontro com ele, condicione uma felicidade eterna.

O conteúdo das Migalhas pode parecer estranho àquele que busca a especulação filosófica: a linguagem não atende à exigência de objetividade e a escrita promove mais um meditar sobre o tema do que sua compreensão direta. Somente com a leitura de todo o livro, e mais ainda de seu Post-Scriptum, fica clara a proposta de Climacus. Este se assume como incapaz de escrever um sistema filosófico. Opõe, à dúvida especulativa, a fé, que não é um conhecimento, mas um ato de liberdade e uma expressão da vontade. O nada poder afirmar ou concluir não é, para Climacus, uma necessidade filosófica, e sim uma 
decisão da vontade; portanto, não é obrigatório nela permanecer.

A fé é o oposto da dúvida. Fé e dúvida não são duas espécies de conhecimento que se deixam determinar no prolongamento uma da outra; pois nenhuma das duas é um ato de conhecimento e elas são paixões opostas. A fé é o sentido que capta o devir, e a dúvida o protesto contra toda conclusão que quer ir além da percepção imediata e do conhecimento imediato. O duvidador não nega, por exemplo, sua própria existência, mas não conclui nada; pois não quer ser iludido (ibidem, p. 123).

Em suma, Climacus propõe ir além do socrático ao defender: ao invés da consciência de estar na verdade eternamente, a consciência de estar na não-verdade; ao invés da ocasião, o instante decisivo; em lugar do mestre ocasional que interroga e passa adiante, o mestre como o deus no tempo, comprometido com o estado ulterior do discípulo e pessoalmente envolvido com ele. Contudo, Climacus jamais diz que seu projeto seria mais verdadeiro que o de Sócrates, e assim conclui:

Este projeto ultrapassa, indiscutivelmente, o socrático, coisa que se mostra em cada ponto. Que seja ou não, por isso, mais verdadeiro do que o socrático, é uma questão completamente diferente, que não se deixa decidir no mesmo alento, dado que aqui admitiu-se um novo órgão: a fé, e uma nova pressuposição: a consciência do pecado, uma nova decisão: o instante, e um novo mestre: o deus no tempo, sem os quais verdadeiramente eu não teria ousado apresentar-me ante a inspeção do grande mestre da ironia, admirado através dos milênios, de quem me aproximo com o coração saltando de entusiasmo como diante de mais ninguém. Mas ultrapassar Sócrates, quando se diz essencialmente o mesmo que ele, só que apenas não tão bem, isso pelo menos não é socrático (ibidem, p. 157).

Climacus não é cristão, mas faz a passagem do ético ao religioso dentro da estratégia kierkegaardiana, escrevendo de acordo com as categorias e o modo grego de raciocinar.

\section{Doença mortal é o desespero}

Na obra A Doença Mortal, traduzida no Brasil como O Desespero Humano $^{5}$ (KIERKEGAARD, 1849/2002), a polêmica entre paganismo e cristianismo é apresentada pelo autor pseudonímico Johannes AntiClimacus $^{6}$. Este personagem assina também Exercício do Cristianismo, publicado em 1850, e é "um cristão em seu mais alto nível": assume a 
defesa do cristianismo de forma clara e direta, ressaltando suas diferenças e avanços em relação ao paganismo. (PAULA, 2009, p. 90). Segundo a concepção de Anti-Climacus, o paganismo é uma forma de desespero, a doença que ele descreve, um desespero de ser si próprio na tentativa de constituir-se a si mesmo de forma totalmente autônoma e independente, sem levar em conta que se tem um 'Autor' e se está em presença dele.

Ao assumir a defesa do cristianismo e contrapô-lo ao paganismo, AntiClimacus não deixa de reconhecer a importância deste último: a retomada da ignorância socrática parece-lhe ponto de partida muito útil em meio à farsa da cristandade e à especulação da moderna filosofia. Crítico da especulação imparcial e indiferente da ciência e da filosofia, que assim evitam se posicionar, Anti-Climacus propõe uma forma de exposição que, conquanto rigorosa, seja também edificante. ${ }^{7} \mathrm{~A}$ especulação cristã, ao contrário da científica, "desumana curiosidade", deve preservar a intimidade do pensamento com a vida, o que constitui seu aspecto ético (KIERKEGAARD, 1849/2002, p. 13); toda especulação filosófica deve igualmente fazê-lo, mas isso ordinariamente não ocorre. As ciências imparciais, por sua vez, se tomam como sérias, mas sob essa capa o que se encontra é farsa ou vaidade.

\section{0 desespero, doença universal}

$\mathrm{Na}$ primeira parte da obra, Anti-Climacus apresenta a definição do desespero, estabelece sua universalidade e as suas personificações.

Define o homem como espírito e o espírito como "eu" - relação que se estabelece apenas consigo mesma; o orientar-se dessa relação para a própria interioridade; conhecimento que a relação tem de si mesma após estabelecida. O homem não é, pois, mera ligação entre alma e corpo. Havendo uma relação que conhece a si própria, tem-se um terceiro termo positivo, que difere dos outros dois. O eu não colocou a si mesmo: foi posto por um autor, com o qual se relaciona. É liberdade, ao se relacionar consigo mesmo, e ao mesmo tempo derivado.

Justamente por se constituir como essa relação consigo mesmo e com Deus, o "eu" desespera: des-espera de si, querendo ser outro; às vezes, querendo ser Deus. Des-espera de Deus, querendo ser si mesmo de maneira auto-suficiente. Nas duas formas há uma recusa de Deus e do eu.

Anti-Climacus define o homem como "uma síntese de infinito e de finito, de temporal e de eterno, de liberdade e de necessidade [...]." (KIERKEGAARD, 1849/2002, p. 19). O eu surge como consciência dessa síntese: "[...] se a relação se conhece a si mesma, esta última relação 
que se estabelece é um terceiro termo positivo, e temos então o eu" (idem, p. 19-20). A relação se orienta para si própria e se relaciona também com quem estabeleceu toda a relação - o autor, como diz AntiClimacus, que é Deus. O fato de ser orientada para si própria e ao mesmo tempo estabelecida por outrem provoca uma discordância, que se manifesta quando o eu quer, ou não quer, ser si próprio. Não há como conseguir o equilíbrio e o repouso apenas relacionando-se consigo, negando sua dependência do conjunto da relação. Só é possível superar o desespero quando o eu se relaciona com o que o pôs no conjunto da relação, quando, "existindo em si, se reflete além disso até o infinito na sua relação com o seu autor." (ibidem, p. 20). "Essa é a fórmula que descreve o estado do eu, quando deste se extirpa completamente o desespero: orientando-se para si mesmo, querendo ser ele mesmo, o eu mergulha, através da sua própria transparência, até o poder que o criou." (ibidem, p. 20).

O desespero é uma doença da alma, do "eu", e seu antídoto é a fé. É mortal como uma doença mortal, da qual só se pode falar enquanto se está vivo. Pode ser comparado a um tipo de fogo que queima sem consumir. Constitutivo do modo próprio de existir do ser humano, e apenas dele, acompanha-o enquanto ele viver, sem matá-lo no sentido físico. É o pior dos males, pois dele sequer se pode morrer. "Quem desespera não pode morrer. Dessa maneira, como um punhal não serve para matar pensamentos, também o desespero, verme imortal, fogo inextinguível, não devora a eternidade do eu, que é o seu próprio sustentáculo" (ibidem, p. 24).

Querer libertar-se de si mesmo é a fórmula de todo o desespero. A segunda fórmula é querer desesperadamente ser si mesmo, o que implica separar-se de seu autor. O esforço é inútil: "[...] este Autor permanece o mais forte e constrange-o a ser o eu que ele não quer ser." (ibidem, p. 25). Esse constrangimento é o seu suplício, pois não pode libertar-se de si mesmo para tornar-se um eu de sua própria invenção.

O desespero é universal, é o preço pago pelo fato de se ter um eu, isto é, consciência de si mesmo, e de ter recebido a tarefa de não somente viver, porque isso as outras espécies também fazem, mas de existir como espírito, ou seja, mais do que síntese de corpo e alma. O desespero é a "inconsciência em que os homens estão de seu destino espiritual" (ibidem, p. 29). É simultaneamente uma vantagem e uma imperfeição. Vantagem por diferenciar o homem das outras espécies; imperfeição, por ser uma enfermidade espiritual que o acompanha. AntiClimacus diz que o "psicólogo" conhece o desespero, enfermidade espiritual, assim como o médico reconhece um mal físico ainda que o 
paciente diga que vai muito bem (ibidem, p. 28).

Mesmo no âmago da mais profunda felicidade há desespero. Aliás, segundo Anti-Climacus, trata-se do seu lugar predileto. O desespero é considerado pelo senso comum uma exceção, quando é, de fato, a regra. A maior parte vive em uma falsa despreocupação, uma falsa satisfação em viver, "que é o próprio desespero" (ibidem, p. 30-31). A existência é desperdiçada quando se é iludido pelas tristezas e alegrias da vida, o que faz com não se atinja a consciência de ser um espírito, um eu, o que constituiria "um ganho decisivo para a eternidade." (ibidem, p. 31). Também não consegue, este iludido, "constatar ou sentir profundamente a existência de um Deus", nem de que ele existe para esse Deus. (ibidem, p. 31). Adquirir essa consciência, que leva à conquista da eternidade, é o que menos interessa ao indivíduo, que se entretém com o que menos importa. Uma vida sem essa aquisição é desespero, e o pior indício desta doença é justamente o seu segredo, é o fato de estar tão dissimulada, ou mesmo ser tão natural, aceita e até estimulada, que o homem dela não se dá conta. Os ideais contemporâneos de felicidade, relacionados à posse material, juventude, beleza, força, vitória, fama, enfim, a incitação à euforia perpétua (BRUCKNER, 2002), consistem, nesta perspectiva, em desespero.

$O$ desespero se personifica em algumas formas. O autor as classifica de acordo com os fatores de síntese do eu e com a consciência ou inconsciência de se ter um eu. No primeiro caso, está o desespero do finito e do infinito, dos possíveis e necessários. O finito delimita e o infinito ilimita. Perder-se no infinito é tornar-se abstrato, imaginário e afastar-se de si mesmo. Passa-se a fazer parte de idéias gerais, como a de humanidade, por exemplo.

Já o desespero do finito por carência do infinito traz estreiteza. Desta vez o eu se perde não porque evapora no imaginário, mas porque se fecha no finito, "e porque em vez dum eu se torna um número, mais um ser humano, mais uma repetição dum eterno zero" (ibidem, p. 36). Isso não significa que deva renunciar a si mesmo, querendo ser outro, mas a falta do infinito pode fazer com que este eu passe a "contemplar as multidões à sua volta, a encher-se com ocupações humanas", esquecendo-se de si mesmo e acreditando ser muito mais simples e seguro "assemelhar-se aos outros, ser uma imitação servil, um número, confundido no rebanho" (ibidem, p. 37).

Este desespero facilita a vida: vida inclusive considerada sábia, porque sem riscos, bem ajustada.

$\mathrm{Na}$ outra personificação quanto aos fatores de síntese do eu, há o desespero do possível, que carece de necessidade, e o de necessidade, que carece do possível. No primeiro, a necessidade exerce no campo do 
possível a função de reter. "O eu é necessidade por ser ele mesmo, e é possível, porque deve realizar-se" (ibidem, p. 38). Ou seja, é limite e possibilidade ao mesmo tempo. O eu, nesta forma de desespero, se debate na abstração do possível, sem sair do lugar. Nenhuma realidade se forma, não há passagem do possível ao real. Tudo parece possível.

Já carecer de possível equivale a ser mudo. De acordo com AntiClimacus, quando todas as possibilidades se esgotam e não há mais nenhum possível humano, é preciso decidir se se quer acreditar que a "Deus tudo é possível" (ibidem, p. 40). Significa perder a razão para ganhar Deus, o que é o ato de crer, a fé. A fé, portanto, é um ato, não simplesmente uma crença. O possível faz respirar e reviver, é o antídoto do desespero e o "combustível da fé"; a falta do possível sufoca (ibidem, p. 42). O fatalista e o determinista só vêem a necessidade. "Não respira o eu do determinista, porque a necessidade pura é irrespirável e asfixia inteiramente o eu. Consiste o desespero do fatalista em ter perdido o eu ao perder Deus" (ibidem, p. 42). Já os filisteus ${ }^{8}$ se entregam à banalidade, da qual o espírito está ausente. Sem imaginação, vivem ao correr dos acontecimentos, no curso habitual das coisas.

Quanto à categoria da consciência, o desespero pode ser: o que se ignora e o consciente. Este último se divide em não querer ser si mesmo - nas categorias do temporal e do eterno - e querer ser si mesmo.

Aquele que ignora ser desesperado ignora ter um eu. Está mais distante da verdade do que o desesperado consciente que se obstina em sê-lo, embora, em outro sentido, este último desespero seja pior por ser mais intenso. Nesta ignorância, o homem tem menor consciência de ser espírito, leva uma vida vegetativa ou uma vida múltipla, agitada. "E quando se suspende o encantamento das ilusões dos sentidos, já que a existência vacila, o desespero, que se ocultava, surge" (ibidem, p. 45). Esta forma de desespero é a mais freqüente no mundo. Anti-Climacus diz que tanto o paganismo antigo quanto a cristandade, que ele chama de "paganismo do nosso tempo", constituem esta espécie de desespero. O pagão e o homem da cristandade não se dão conta de que são desesperados. Ambos carecem de espírito, não no sentido estético de arte e ciência, enobrecimento e prazer, e sim no ético-religioso.

Todo homem que não se conhece como espírito ou cujo eu interior não tomou em Deus consciência de si mesmo, toda existência humana que não mergulha desse modo limpidamente em Deus, mas se funda nebulosamente sobre qualquer abstração ou a ela se reduz - Estado, Nação etc. -, ou que, cega para consigo mesma, não vê nas suas faculdades mais do que energias de origem pouco explícita, e aceita o seu eu como um enigma rebelde a qualquer introspecção - toda existência deste gênero, realize o que realizar de extraordinário, explique o que 
explicar, até o próprio universo, por muito interessante que, como esteta, goze a vida, com tudo isso, ela será desespero (ibidem, p. 47).

As virtudes pagãs seriam vícios brilhantes, já que, por não se conhecer como espírito frente a Deus, o íntimo do pagão é desespero. AntiClimacus aponta, entretanto, uma diferença entre o paganismo de outrora e o moderno. Ainda que o paganismo não conhecesse o espírito no sentido cristão, estava orientado para ele, o que lhe dava vantagem sobre os pagãos modernos, que "carecem dele por afastamento ou traição, e isso é que é a verdadeira nulidade do espírito" (ibidem, p. 4748).

No desespero consciente, há uma grande variabilidade de matizes, estendendo-se da inconsciência total à consciência completa.

O desesperado pode quase perceber seu desespero, mas no dia seguinte atribui o mal-estar a outra origem, como se fosse algo exterior.

A intensidade do desespero aumenta com a consciência; correlativamente, conhecer o próprio estado de desespero faz com que cresça a consciência do eu e, com isso, a possibilidade de superação do desespero. Anti-Climacus diz que o contrário de desesperar é crer. A fórmula do estado no qual o desespero foi eliminado é a fórmula da fé, que ele assim define: "descendo em si próprio, querendo ser si mesmo, o eu mergulha através da sua própria transparência no poder que lhe deu existência" (ibidem, p. 49).

$O$ desespero consciente se apresenta sob duas formas: a) o desespero em que não se quer ser si mesmo, ou desespero-fraqueza, que pode ser desespero do temporal ou de uma coisa temporal, e desespero quanto ao eterno ou de si mesmo; b) o desespero no qual queremos ser nós mesmos, ou desespero-desafio. As duas formas estão relacionadas, pois querer ser si mesmo é também uma forma de desespero na qual, efetivamente, o que se quer é ser um eu de própria invenção, é ser autor de si próprio. Ao mesmo tempo, nas duas formas há desafio, pois o que não quer ser si mesmo também gostaria de inventar-se sozinho, não aceitando ter sido lançado pelo seu Autor. A diferença entre as duas formas é, pois, relativa.

No desespero do temporal ou de uma coisa temporal, o indivíduo se encontra frente ao puro imediato, ao imediato como reflexão quantitativa. Trata-se do homem do espontâneo, desprovido de reflexão, que reage ao que the vem de fora. E apenas uma coisa a mais, um detalhe na imensidade do temporal, parte integrante do mundo material, em face do qual é passivo. Não se vê como eterno. Não possui outra dialética "que não seja a do agradável e do desagradável, nem outros conceitos além do de felicidade, infelicidade e fatalidade" 
(ibidem, p. 51). Se um golpe o atinge de fora naquilo que the é mais caro - posses, status, relacionamentos, juventude, beleza e saúde -, torna-se infeliz e é aniquilado de imediato, não conseguindo regressar. Este desesperado crê que sua infelicidade vem da perda de algo temporal, mas, para Anti-Climacus, seu desespero está em perder a eternidade, em carecer do eterno e em apostar tudo no temporal. Deste ponto de vista, quando ele recebe um golpe do destino e se desespera aos olhos do mundo, isso significa que sua vida pregressa já era desespero, embora passasse por um "excesso de felicidade" (ibidem, p. 52). Para este homem do temporal, se o exterior volta a ser como antes, ele se sente renascer. Mas não se dá conta de ser um eu.

Ora, esse é o desespero do imediato: não se querer ser si próprio, ou, menos ainda: não se querer ser um eu, ou forma inferior a todas: desejar ser outrem, aspirar a um novo eu. [...] $O$ homem do imediato, ao desesperar, nem sequer tem eu suficiente para ao menos desejar ou sonhar ter sido aquilo que não foi. Então, defende-se de outra maneira, desejando ser outrem. Observe quem se quiser certificar os homens do espontâneo: no momento do desespero, o primeiro desejo que Ihes vem, é terem sido ou tornarem-se outros (ibidem, p. 53).

Anti-Climacus considera cômico este homem apaixonado pela ilusão de que pode transformar-se em outro assim como troca de roupa. Como não se conhece a si mesmo, só se reconhece na vida exterior, pela vestimenta. E se pudesse tornar-se outro, se arranjasse um novo eu, poderia depois reconhecer-se?

Quando um pouco de reflexão sobre si mesmo se mistura ao imediato, o desespero se modifica. Com alguma consciência do seu eu, o homem se torna igualmente um pouco mais consciente do que é o desespero e do próprio estado. Embora ainda seja um desespero passivo, em que não se quer ser si mesmo, o progresso está em que o desespero não vem de um choque, mas da reflexão. Não há mais uma simples submissão passiva a coisas exteriores, mas um esforço pessoal, um ato - um começo de diferenciação entre o eu e o mundo exterior. Porém, tal consciência do eu o incomoda: é um vago mal-estar, que o desesperado espera passar.

O desespero quanto ao eterno ou de si mesmo vem a ser o mesmo que o desespero do temporal ou de uma coisa temporal. É por dar tanto valor ao temporal ou a uma coisa temporal que o indivíduo desespera quanto à eternidade; ou seja, não se vê como um eu que é, ao mesmo tempo, temporal e eterno. Esta forma é um progresso, na visão de AntiClimacus. O desesperado, neste caso, já percebe como fraqueza o fato de dar tanto valor ao temporal. Entretanto, ainda não chega à fé. Ao 
invés de humilhar-se "perante Deus" em função de sua fraqueza, mergulha no desespero por causa dela (ibidem, p. 60). Já não desespera então de algo temporal, mas de si mesmo. Com o crescimento da consciência, aumenta a intensidade do desespero, porém igualmente a possibilidade de "salvação", pois "a sua própria profundidade o salva do esquecimento" (ibidem, p. 60). Essa forma é redutível à do desespero no qual queremos ser nós mesmos. $O$ eu não quer se reconhecer após tanta fraqueza, mas não a pode esquecer. Abomina-se, todavia não quer, "como o crente, humilhar-se sob ela para assim se encontrar" (ibidem, p. 60). Não quer saber de si, mas tampouco consegue esquecer-se - como um pai que deserda o filho, sem conseguir afastá-lo do pensamento. Este desesperado, pouco freqüente, procura manter os aspectos de uma vida normal a fim de conservar os importunos à distância (ibidem, p. 61).

Ao mesmo tempo, ele necessita de solidão, o que é indício de uma "natureza mais profunda", que já não necessita do "murmurejar tranqüilizador da sociabilidade" (ibidem, p. 62).

Anti-Climacus lembra que a solidão era valorizada na Antiguidade e na Idade Média, ao passo que nossa época treme diante dela, e só a utiliza contra os criminosos. Os que amam a solidão são também vistos como criminosos, pois "é um crime dedicar-se ao espírito" em uma época de perpétua sociabilidade. (ibidem, p. 62).

O autor pseudonímico fala, em seguida, sobre o desespero-desafio: aquele em que se quer ser si próprio. $O$ eu recusa-se a se perder, o que seria o caminho para novamente se encontrar. Tal perspectiva interessa particularmente à psicologia: Anti-Climacus propõe justamente um despedaçar-se e perder-se de si mesmo, em oposição à busca desesperada por ser si mesmo do mundo psico-lógico. O projeto de Anti-Climacus pode ser encarado como desconstrução do si mesmo, do eu íntegro e coerente, suposto fundamento transcendental imutável de cada um, na direção do eu como síntese dos paradoxos da existência, que não é passível de definição ou teoria, pois só pode ser apreendido a cada instante na ação: sendo sempre um tornar-se, nunca é um. Encontrar a si mesmo seria, neste sentido, deparar-se com o fato de que não há um si mesmo como essência, apenas no diálogo-relação consigo mesmo. O termo perder-se pode ser compreendido como sair do subjetivismo, como abandono do eu psicológico em favor do existencial, somente apreensível em relação com o mundo, com os outros homens e com Deus.

No desafio, o desesperado quer se isolar de qualquer relação com um "poder que Ihe deu resistência" (ibidem, p. 65). Não admite qualquer poder acima dele. 
Este desespero é chamado por Anti-Climacus de "estóico" (ibidem, p. 65), dado que o sujeito constitui a si mesmo através de exercícios. Ao invés de admitir que Deus o contempla, o desesperado se contempla, conferindo aos seus empreendimentos um interesse e um sentido infinitos. Neste caso, "rouba-se a Deus a idéia de que ele nos contempla." (ibidem, p. 66).

O desespero reside no fato de que um eu derivado se tome por mais do que é. Diz Anti-Climacus que, ao tentar ser si mesmo, isto é, criar uma essência fixa, o eu acaba dissolvido no seu contrário até deixar de ser um eu, ou seja, deixar de ser uma abertura. "Em toda dialética que enquadra sua ação, nem um ponto fixo. O que o eu é, em nenhum momento adquire constância, uma eterna constância." (ibidem, p. 66). Dizer que o eu é senhor em sua casa representa desespero, embora isso seja tomado, habitualmente, como satisfação e prazer. Para AntiClimacus, este príncipe é um rei sem reino, que governa sobre nada. "O homem desesperado, então, se perde construindo castelos no ar e batese sempre contra moinhos de vento." (ibidem, p. 66). O eu desesperado quer existir por si mesmo e receber as honras por sua autoconstrução, mas, quando crê terminar o edifício, "tudo pode, arbitrariamente, desvanecer-se no nada." (ibidem, p. 66).

O desesperado do temporal não vê consolação no eterno; já o desesperado que desafia não admite que uma miséria temporal the possa ser tirada: prefere manter-se no próprio tormento do que gritar por socorro. Ou, ao contrário, aceita ser auxiliado, desde que a ajuda Ihe seja dada ao seu modo e no momento por ele definido. Se assim não for, prefere permanecer como "a injustiçada vítima dos homens e da vida, permanecer aquele que vela por guardar à vista o seu tormento para que não lho tirem - caso não, como comprovar o seu direito e convencer-se a si mesmo?" (ibidem, p. 68).

O desespero no qual não se quer ser si mesmo constitui, ao ver de AntiClimacus, a forma mais baixa de todas; porém aquele em que se quer ser si mesmo é a forma mais condensada do desespero. Pois não é para prosseguir no próprio aperfeiçoamento que o eu quer ser ele mesmo, como no caso do estoicismo, mas "por ódio à existência e segundo a sua miséria." (ibidem, p. 69-70). Mantendo-se com o seu tormento, o desesperado quer protestar contra a vida, ser a própria objeção contra a existência; por isso não pode aceitar qualquer consolação. Assim age o desesperado que quer ser si próprio, orgulha-se do próprio tormento e não acata o auxílio do "'Socorredor', a quem tudo é possível." (ibidem, p. 68). Acredita-se especial por ter um espinho na carne como sinal de uma missão extraordinária, e não vê que deveria retomar o seu lugar entre o comum dos homens. 


\section{Desespero e pecado - entre paganismo e cristianismo}

$\mathrm{Na}$ segunda parte da obra, Anti-Climacus explora os nexos entre desespero e pecado. Procede a uma confrontação entre paganismo e cristianismo, distinguindo a concepção socrática do pecado da concepção cristã, por ele defendida.

Define "pecado" como a ação de querer, ou não, ser si próprio frente a Deus ou à idéia de Deus. O pecado é fraqueza ou desafio "elevados à suprema potência." (ibidem, p. 73). O que faz com que haja tal intensidade e gravidade no desespero é o fato de estar frente a Deus. A vida estética, definida pelo personagem Anti-Climacus como aquela onde apenas se sonha ao invés de ser, onde a relação com o bem e com a verdade é mantida apenas na imaginação, ou seja, uma vida especulativa, é pecado aos olhos do cristão, que defende, como faz esse personagem kierkegaardiano, a necessidade de a existência ser assumida como uma tarefa séria, com a qual é preciso implicar-se do início ao fim. Em Ponto de vista explicativo da minha obra de escritor (1849/1986) o próprio Kierkegaard descreve o modo como assumiu sua tarefa como autor, dedicando-se a lançar, através de seus livros, um grito de alerta ao leitor, tornando-o atento.

Na primeira parte de O Desespero Humano, Anti-Climacus apreciara o eu cuja medida era o homem; agora quer falar sobre a gradação da consciência do eu frente a Deus, o que Ihe dá uma nova qualidade: o eu humano se torna "'eu teológico', o eu em face de Deus" (ibidem, p. 75) e, pela consciência de estar frente a Deus, ganha uma realidade infinita. Nesta linha, Anti-Climacus diferencia o homem natural, que relaciona ao paganismo, do homem como espírito, vinculando-o ao cristianismo: a diferença entre ambos está em se reconhecer, ou não, na presença de Deus. O fato de o pecado ser não apenas contra os homens, mas contra Deus, o torna mais grave, eleva-o à infinita potência. $O$ eu do pagão não estava frente a Deus, sua única medida era o homem, porque até os deuses eram antropomórficos. O pecado do paganismo era, pois, a ignorância desesperada de Deus, embora os pagãos reconhecessem o divino. No sentido estrito, não havia pecado, porque não se agia perante Deus. Já com o cristão, qualquer pecado "o é perante Deus. [...] Pecase quando, frente a Deus, desesperados, não queremos ou queremos ser nós mesmos." (ibidem, p. 76 e 77).

Ao invés de em desespero, não se deveria antes falar de homicídio, roubo? Para Anti-Climacus, é evidente que também nestes casos há obstinação contra Deus, e que são igualmente formas de desespero. 
Mas falar apenas de tais faltas "é esquecer facilmente que, até certo ponto, se pode estar em tudo isso em regra com os homens", sem que por isso a vida deixe de ser pecado. (ibidem, p. 77).

Os chamados "pecados da carne" representam, para Anti-Climacus, uma obstinação; logo, desespero de ser si próprio, categoria do espírito. (ibidem, p. 77). O pecado, adverte o autor pseudonímico, "não é o desregramento da carne e do sangue" em si mesmo, "mas o consentimento dado pelo espírito a esse desregramento", estando ele perante Deus. (ibidem, p. 77). Conseqüentemente, não cabe dizer que a carne é fraca.

O contrário do pecado não é a virtude, como se costuma pensar, mas a fé. Há então um face-a-face entre cada homem isolado e Deus. AntiClimacus critica os filósofos que procuram "universalizar imaginariamente os indivíduos na espécie." (ibidem, p. 78).

O escândalo está em que Deus veio ao mundo, se deixou encarnar, sofreu e morreu, e ainda pede ao homem que aceite o socorro que the é oferecido. Por não compreender este oferecimento, o homem se escandaliza. "Em sua estreiteza de coração, o homem natural é incapaz de se conceber o extraordinário que Deus Ihe destinava." (ibidem, p. 80). Anti-Climacus nega que seja necessário defender o cristianismo. Defendê-lo seria fazer dele algo lamentável a ponto de precisar que o advogassem. Defender o cristianismo é algo próprio da cristandade, que assim o trai. "Advogar desacredita sempre." (ibidem, p. 81). É incrédulo aquele que defende o cristianismo, visto que o entusiasmo da fé nunca é uma defesa, sempre "um ataque, uma vitória." (ibidem, p. 82).

$\mathrm{Na}$ definição socrática - aqui no sentido de homem pagão -, pecar é ignorar. Anti-Climacus pretende servir-se de tal definição "tão profundamente grega." (ibidem, p. 82) para salientar ângulos do cristianismo. Aponta como defeito na definição socrática o fato de deixar vago o sentido preciso da ignorância e sua origem. Seria ela original ou adquirida? Se adquirida, é fruto de uma atividade íntima do homem que obscurece a consciência; no caso, porém, não se trata de ignorância, mas da vontade. Para o cristianismo, nem o pagão nem o homem natural sabem o que é o pecado. Ao ver de Anti-Climacus, o que falta à definição socrática é a vontade, o desejo.

A intelectualidade grega era demasiado feliz, demasiado ingênua, demasiado estética, demasiado irônica, demasiado maliciosa... demasiado pecadora para chegar a compreender que alguém tendo o seu saber, conhecendo o justo, pudesse cometer o injusto. O helenismo dita um imperativo categórico da inteligência. (ibidem, p. 84). 
A vontade também interfere no não querer saber o que é o justo. AntiClimacus distingue, assim, o pecado por ignorância e o pecado pela decisão. Saber e compreensão "permanecem sem ação na vida dos homens, na qual nada se manifesta do que compreenderam, antes pelo contrário!" (ibidem, p. 84). Há, pois, em geral, uma discordância entre o que se sabe e o modo como se age, o que demanda levar em conta a vontade. Se a não compreensão do que é o justo fosse a responsável pela injustiça, Sócrates teria razão: aquele que se finge de justo não peca, apenas não compreendeu o que é o justo. Mais uma vez, AntiClimacus discorda: o pecado, que significa ação, decisão, não é uma negação, um vazio; é uma posição: a vontade, a decisão, é que levam à ação.

No paganismo, ao exercitar novos modos de pensar, a ação em situações concretas se daria adequadamente, pois se estaria para elas preparado. No cristianismo, pondera Anti-Climacus, o instante é decisivo e, nele, decide-se a partir da vontade, não do pensamento previamente exercitado. Neste sentido, afirma o autor: "A filosofia moderna não é, como se vê, senão paganismo". (ibidem, p. 87). Essa filosofia relaciona diretamente pensamento e ser, pensamento e ação, sem a intermediação da vontade - situação concebível, mas jamais efetivamente vivenciada. Na vida real, quando se trata do indivíduo existente - aquele que interessa a Anti-Climacus -, não há como evitar a passagem do compreender ao agir; embora minúscula, ela não pode ser percorrida com pressa.

Para o cristianismo, o pecado não está em não compreender o justo, "mas em não querer compreendê-lo, em não querer o justo." (ibidem, p. 88). Anti-Climacus põe em destaque a diferença entre não poder e não querer compreender, enquanto Sócrates distinguia compreender efetivamente e compreender mal, ou não compreender, o que era o justo. Ao passo que, para Sócrates, só a incompreensão poderia levar a não praticar o justo, para Anti-Climacus o cristianismo vai mais longe, ao dizer que é por não querer o justo que o indivíduo se recusa a compreendê-lo. Nesta perspectiva, é possível abster-se do que é justo ou praticar o injusto, embora se compreenda o que é justo. "Dessa forma, para o cristão o pecado está na vontade e não no conhecimento." (ibidem, p. 89). O pecado é uma posição, não uma negação sob a forma de ignorância ou ausência de compreensão.

Mesmo discordando da perspectiva socrático-pagã, Anti-Climacus admite que essa ignorância socrática seria muito útil aos cristãos da cristandade, caso aplicada ao cristianismo, pois os desencorajaria de tentar compreendê-lo de forma especulativa, como um saber conceitual. $\mathrm{O}$ autor considera que a admissão de que não temos o poder nem o 
dever de compreender é um dever ético. Ressalta que a ignorância socrática constituía uma "espécie de receio e de culto a Deus" (ibidem, p. 91) - receio e culto que os pretensos cristãos não possuem. Ainda de acordo com Anti-Climacus, a ignorância socrática

[...] transpunha para grego a idéia judaica do terror de Deus, começo da sabedoria. Era por respeito da divindade que ele era ignorante, e, tanto quanto o podia um pagão, que guardava como juiz a fronteira entre Deus e o homem, tratando de reforçar a diferença de qualidade entre eles por um fosso profundo, a fim de que Deus e o homem não se confundissem [...]. Essa é a causa da ignorância de Sócrates. Eis porque a divindade reconheceu nele o mais alto saber. (ibidem, p. 91).

O estado contínuo de pecado seria, conforme Anti-Climacus, um pecado a mais. "Estacionar no pecado é pior do que cada pecado isolado, é o pecado por excelência." (ibidem, p. 98). Raros são os homens cuja consciência interior tem continuidade, no sentido de atenção às próprias ações cotidianas. Sua consciência é, habitualmente, uma simples intermitência, que só se manifesta nas decisões graves. "Como espírito, o homem não existe durante mais de uma hora por semana... forma bem animal, evidentemente, da existência espiritual." (ibidem, p. 97).

Pecar é afastar-se do bem, e não se arrepender é pecar ainda mais intensamente. Ao invés da humilde contrição que pede perdão a Deus e que espera em Deus a remissão do pecado, o desesperado afirma que, no seu caso, não há salvação possível. Ele decide isto, e no seu orgulho, quando diz "jamais perdoarei", há desespero. (ibidem, p. 103). Não ousa crer na remissão dos pecados ou se recusa a nela crer.

A medida da espiritualidade a ser alcançada pelo eu é o Cristo. Através da figura do Cristo, Deus é a medida do homem e o seu fim. É ao reconhecer a diferença entre si mesmo e Deus que o homem está mais próximo Dele. Ao se confundir com Deus e se tomar por um homemdeus é que se afasta. Segundo Anti-Climacus, reina então uma desordem no terreno religioso porque, nas relações do homem com Deus, o "tu deves" foi suprimido. (ibidem, p. 106). Em seu lugar utilizase a idéia de Deus como "um condimento da importância humana, para se fazer de importante perante Deus." (ibidem, p. 106). Ou seja, o colocar-se como opositor a Deus faz com que, ao ser contra ele, alguém possa se sentir importante.

Qual em política, em que se consegue importância colocando-se na oposição, a ponto de por fim, se desejar um governo para encontrar alguma coisa a que se opor, tal como se acabará por não querer suprimir Deus... apenas para se encher de mais 
importância do estar na oposição. (ibidem, p. 106).

Tal obstinação - dizer que é impossível crer - passa por "profundeza". $\mathrm{Na}$ verdade, argumenta Anti-Climacus, não se quer fazer o que se deve. Enquanto os pagãos nomeavam Deus, ou 'o divino', com toda solenidade, por medo do mistério, entre os cristãos seu nome é "a mais corrente das palavras de todos os dias". Ao mesmo tempo, é "a mais vazia de sentido, e a que se usa com menos cautela $[\ldots]$ ". (ibidem, p. 106).

O fato de Cristo querer absolver os pecados escandalizou, em sua época. Para a razão humana, trata-se de algo impossível de ser apreendido: acredita-se ou não. O pagão não identificava o pecado nem sua remissão, porque não tinha a medida necessária, a idéia de Deus. O cristão sabe o que é o pecado, como sabe o que é o desespero, e deve crer na sua remissão. Porém a cristandade nem mesmo conhece o seu estado. Não atingiu a consciência do pecado no sentido cristão, só reconhece o que já era reconhecido pelo paganismo, "vive alegre e contente numa pagã segurança." (ibidem, p. 107).

O cristianismo exige uma apropriação, que é o contrário da especulação; dirige-se ao indivíduo, em contraste com a multidão. Abstrações como povo, populaça, multidão, público, não existem para Deus. Para Ele, frisa Anti-Climacus, só há indivíduos. "Ele faz de cada homem um indivíduo, um pecador particular, e depois junta aquilo que, entre o céu e a terra, se encontra de possibilidade de escândalo: eis o cristianismo. A seguir ordena que creia a cada um de nós, ou seja, diz-nos: Escandaliza-te ou crê." (ibidem, p. 111).

Há ainda o pecado de negar o cristianismo, a escolha de abandoná-lo. Aqui o eu se eleva ao grau supremo de desespero, ao considerar o cristianismo como mentira e fábula. Na guerra que trava contra Deus, o homem passa, neste caso, da defensiva à ofensiva. "No paganismo é o homem que reduz Deus ao homem - deuses antropomórficos. No cristianismo é Deus quem se torna homem - homem-deus." (ibidem, p. 114). Igualar-se a Deus é, para Anti-Climacus, um escândalo, pois são naturezas, a do homem e a de Deus, infinitamente diferentes. Por isso, só se pode crer no paradoxo de que o divino se fez homem através da figura do Cristo, e não compreendê-lo. Trata-se de um ato de amor. "Deus faz-se homem por amor e diz-nos: 'Vede o que é ser homem'. Todavia, acrescenta: 'Tomai cuidado, porque ao mesmo tempo sou eu Deus... e bem-aventurados os que não se escandalizam de mim. (ibidem, p. 116). Deus se reveste, como homem, da aparência de um humilde servo, para que ninguém se julgue excluído de se aproximar d'Ele. Ao mesmo tempo é Deus, e não se deve escandalizar-se dele. 
"Meu Pai e eu somos um só, e contudo eu sou este homem de nada, este humilde, este pobre, este desamparado, entregue à violência humana... e bem-aventurados aqueles que não se escandalizam de mim." (ibidem, p. 116). A recomendação que Cristo faz é: "Que cada qual se examine". (ibidem, p. 116). São palavras que é preciso, conforme Anti-Climacus, intimar, reiterar sem descanso, redizer a cada um de nós particularmente. Onde se calem, ou onde a exposição do cristianismo não se penetre desse pensamento, o cristianismo não passará de "blasfêmia". (ibidem, p. 117).

Por fim, Anti-Climacus esclarece que o contraste entre pecado e fé servira de pano de fundo a todo o seu escrito: desde a primeira parte da obra, apresentara o estado de um eu do qual o desespero está totalmente ausente. E esse estado é o seguinte: "Em sua relação com ele mesmo, e querendo ser ele mesmo, o eu mergulha através da sua própria transparência no poder que o criou. Por conseguinte, essa fórmula é a definição da fé, conforme realçamos tantas vezes." (ibidem, p. 119).

\section{Considerações finais}

A julgar pela opinião de Anti-Climacus e pelo combate travado por Kierkegaard contra a farsa da cristandade, o Ocidente nunca foi cristão, embora assim se autodenomine. Primeiro, porque dizer que "o Ocidente é cristão" denota uma generalização que nada tem a ver com a relação pessoal com o cristianismo (KIERKEGAARD, 1846/1949). Segundo, porque mesmo no plano individual, no qual se deveria desenvolver a efetiva relação com o cristianismo, esta não acontece. São priorizadas, segundo Kierkegaard (1849/1986), as categorias estéticas e éticas. Pode-se, consequentemente, concluir que os modos de subjetivação modernos são pagãos? Antes fossem. Neste caso, através da ignorância socrática, a ilusão da cristandade começaria, pelo menos, a ser desfeita. Cuidar de si, do mundo e do outro, agir de maneira coerente com a verdade enunciada já faria uma grande diferença. Afinal, como mostrou Kierkegaard, Sócrates alcançou o mais alto patamar possível na ética pagã. (PAULA, 2009).

Se a ética pagã desapareceu e a cristã está longe de ser praticada, há, no entanto, algumas preocupações tipicamente pagãs que ainda se mantêm. Kierkegaard as considera pagãs porque decorrem do não reconhecimento, pelo homem, de sua condição de criatura, e da descrença em uma providência divina.

O discurso kierkegaardiano As preocupações dos pagãos, de 1848, 
impressiona pela atualidade e é um dos quatro Discursos cristãos do pensador dinamarquês. Nele, Kierkegaard fala sobre sete preocupações: a da pobreza; a da abundância; a da humildade; a do orgulho; a da presunção; a do auto-suplício; a da dúvida, da inconstância, da desconsolação.

O que caracteriza o modo de ser pagão é a preocupação com o que há de acontecer. Referindo-se a um texto do Novo Testamento, Kierkegaard compara essa preocupação com a despreocupação dos pássaros do céu e os lírios do campo. ${ }^{9}$ Por não terem o mesmo tipo de preocupação, os pássaros e os lírios servem como professores para os homens. Não são pagãos nem cristãos, mas auxiliam o cristianismo em uma época de "paganismo cristianizado". (PAULA, 2007, p. 69).

O pagão é caracterizado no texto como aquele que se preocupa com eventos futuros e com a segurança. Neste sentido, Paula (2007) afirma que muitos cristãos podem ser considerados pagãos. Ao usar a imagem dos pássaros e dos lírios, a intenção não é ensinar nem condenar, mas apenas mostrar o que é o paganismo e o que se exige dos cristãos. (PAULA, 2007). Kierkegaard apresenta o pássaro como professor despretensioso, que não se preocupa em ensinar nem se dá conta de que o faz; apenas vive, e seu modo de viver é uma lição silenciosa. Ao observá-lo, vê-se que não se inquieta com a vida material, tampouco com o que acontecerá no dia seguinte. Age no presente. Sócrates, embora nada desejasse ensinar, dirigia-se aos pagãos do seu tempo para interrogá-los e incitá-los a cuidarem de si, ao invés de se preocuparem com a pobreza e a abundância, a humildade e o orgulho, a presunção e a dúvida. Atinge ele a mais alta expressão da ética pagã justamente porque coloca em questão as preocupações do paganismo, deixando para trás o velho helenismo e apenas preparando a aparição do novo princípio. (KIERKEGAARD, 1841/2006). Também Kierkegaard pretende alcançar o leitor através de seus textos, a fim de retirá-lo da ilusão de ser o que não é, e o fazer voltar-se para o que interessa de fato à sua existência como espírito.

Os modos de subjetivação modernos, com suas preocupações, em muito se aproximam do paganismo descrito por Kierkegaard e das formas assumidas pelo desespero. A busca imediata e desenfreada da felicidade e do prazer, da vitória e do sucesso, traz inquietação. Quando algo falha neste projeto, surge o desespero (no caso, o desespero conforme é visto pelo senso comum), revelando que tal forma de viver já era desespero. Aquilo que vem sendo, exclusivamente, considerado como felicidade, leia-se desfrutar a vida através do status, da ostentação e do consumo incessante de objetos, lugares, pessoas, drogas (lícitas e ilícitas), poder etc., para Anti-Climacus, no entanto, não passa de profunda miséria 
espiritual, habitando o âmago da mais tranquila felicidade. Na visão do autor, seria muito menos arriscado perder o mundo, com todos os seus atrativos, distrações e preocupações, do que perder a si mesmo.

Ser desesperado, pagão, especulativo, cristão, ou constituir-se a partir de discursos e práticas tomados como verdades eternas e a-históricas são possibilidades de nosso horizonte como existentes, perante as quais escolhemos e agimos.

Podemos afirmar que a oposição entre a especulação, científica ou filosófica, representada em Migalhas pelo mestre socrático, e a implicação para com a existência, demonstrada na figura do mestre cristão, aponta para modos possíveis de ser e de viver, de se reconhecer e se constituir, modos de subjetivação que estão presentes como possibilidades para cada um de nós. Da mesma forma, os modos de ser pagão e cristão debatidos por Anti-Climacus, personagem que defende o ser cristão como antídoto para a doença mortal, referem-se ao tipo de preocupação que move 0 homem em sua existência. $O$ pagão contemporâneo, como o da época de Kierkegaard, é aquele que se volta para os eventos e situações temporários e transitórios, que possui apreensões quase ou exclusivamente materiais e passa a vida a correr atrás de garantias e segurança, sucesso e vitória, status e satisfações imediatas, sempre temendo perder o que conquistou e que acredita ser a sua vida, ao mesmo tempo sempre insatisfeito com o que possui. Já o cristão nada teme no que se refere a perdas materiais, pois seu olhar volta-se para o que não pode perecer, a sua consciência e os interesses espirituais: prefere perder o mundo a ganhá-lo sob o preço de perder a si mesmo. O que mais teme é o desespero. As duas posições não são destinos, exigindo-se, portanto, do sujeito, sua decisão e posicionamento perante a própria existência.

O psicólogo, em sua prática, defrontar-se-á com essas possibilidades de ser, a partir dos relatos dos clientes e em sua própria experiência. Atuando no modo pagão-desesperado, buscará oferecer soluções imediatas, conselhos produtivos, técnicas para o sucesso, respostas prontas sobre como não ser tímido, vencer a insegurança, eliminar a angústia e a culpa, conquistar um amor, ser bem-sucedido. Do contrário, irá aguardar pacientemente que o outro se revele, escutará aquilo que ele tiver mais prazer em contar sem assombro, a fim de ajudá-lo a desfazer os laços da ilusão nos quais se enredou (KIERKEGAARD, 1849/1986), afastando-se de si mesmo e chegando a esquecer que tem um eu. A comunicação indireta, nesse segundo caso, favorecerá uma aproximação cuidadosa e sutil daquele a quem se pretende ajudar a reconhecer-se e assumir-se em sua singularidade. Anti-Climacus é um personagem ético e como tal, prescreve o ousar ser 
si mesmo e mergulhar até o poder que nos pôs em relação, reconhecendo o Autor; recomenda, ainda, como fórmula para a superação do desespero, a fé. Kierkegaard, por sua vez, não nos parece oferecer uma síntese como solução que resolva e ponha fim à polêmica entre paganismo e cristianismo. Em seu pensamento e em sua existência se mantém, a nosso ver, a dialética entre a estratégia socrática e o ideal cristão, publicando textos estéticos e religiosos ao mesmo tempo, do início ao fim de sua produção, definindo-se como um autor religioso, sem se afirmar, ele mesmo, como cristão.

\section{Referências}

BRUCKNER, P. A Euforia perpétua: ensaio sobre o dever de felicidade. Rio de Janeiro: DIFEL, 2002.

FOUCAULT, M. Le courage de la vérité. Le gouvernement de soi et des autres. Cours au Collège de France, 1983-1984. Paris: Gallimard, 2009.

KIERKEGAARD, S. A. O conceito de ironia constantemente referido a Sócrates. Petrópolis: Vozes, 1841/2006.

. Migalhas filosóficas ou um bocadinho de filosofia de João Clímacus. Petrópolis: Vozes, 1844/2008.

Post-scriptum final non-scientifique aux Miettes

Philosophiques. Paris: Edições Gallimard, 1846/1949.

. O conceito de ironia constantemente referido a Sócrates. Petrópolis: Vozes, 1841/2006.

- Ponto de vista explicativo da minha obra de escritor. Lisboa: Edições 70, 1849/1986.

. O desespero humano. São Paulo: Martin Claret, 1849/2002.

$\overline{M A T T A R}$, C. M. Interfaces e inquietações no diálogo entre Kierkegaard e Foucault - filosofia antiga, psicologia e processos de subjetivação. 2011. 282f. Tese (Doutorado em Psicologia Social) - Universidade do Estado do Rio de Janeiro, Rio de Janeiro.

PAULA, M. G. As preocupações dos pagãos: um discurso de Kierkegaard. In: REDYSON, D.; ALMEIDA, J. M.; PAULA, M. G. (Orgs.). Sören Kierkegaard no Brasil: Festschrift em homenagem a Álvaro Valls. João Pessoa: Idéia, 2007, p. 61-82.

PAULA, M. G. de. Subjetividade e objetividade em Kierkegaard. São Paulo: Annablume; Aracaju: Fapitec-SE, 2009.

VALLS, A. L. M. Entre Sócrates e Cristo. Ensaios sobre a ironia e o amor em Kierkegaard. Porto Alegre/RS: EDIPUCRS, 2000.

. Apresentação. In: KIERKEGAARD, S. A. Migalhas filosóficas 
ou um bocadinho de filosofia de João Clímacus. Petrópolis: Vozes, 1844/2008, p. 9-18.

VERGOTE, H. B. Sócrates e o chapéu que o torna invisível (a partir de Kierkegaard). In: . Ler Kierkegaard, filósofo da cristicidade. Tradução de Álvaro Valls e Lúcia Sarmento da Silva, 2001 (texto digitado).

\author{
Endereço para correspondência \\ Cristine Monteiro Mattar \\ Rua Mariz e Barros, 128/404 B, Icaraí, Niterói, RJ, Brasil \\ Endereço eletrônico: cristinemattar@ig.com.br
}

Recebido em: 20/11/2011

Reformulado em: 02/08/2012

Aceito para publicação em: 20/10/2012

Acompanhamento do processo editorial: Ana Maria Lopez Calvo de Feijoo

\title{
Notas
}

*Professora Adjunta do Departamento de Psicologia da Universidade Federal Fluminense - Rio de Janeiro - Niterói/Brasil; doutora em Psicologia Social pela UERJ.

${ }^{1}$ Há o Sócrates irônico de O Conceito de Ironia (1841); e o Sócrates pagão de Migalhas Filosóficas (1844) e de O Desespero Humano (1849).

2João Clímacus, na tradução para o português empreendida por Ernani Reichmann e Álvaro Valls. Optou-se por citá-lo conforme o original.

${ }^{3}$ Apresentada nos diálogos platônicos: Menon, Fédon e Fedro.

${ }^{4} O$ deus era a expressão grega que queria dizer "o divino", "a divindade". Climacus retoma a expressão, dando a entender, sem dizê-lo diretamente, que é do Cristo que fala. No Post-Scriptum (1846/1949), a referência será direta.

${ }^{5}$ As traduções francesa e brasileira não mantiveram o título original da obra, intitulando-a respectivamente Tratado do Desespero (1949) e O Desespero Humano (2002).

${ }^{6}$ Quase ao final da obra, na página 95, aparece a expressão anticlímax, com a qual o autor Anti-Climacus define a situação daquele que pretende provar a eficácia da oração através de razões objetivas; mas tais razões são vazias diante de algo que supera o entendimento. Pode-se pensar que o desespero é o anticlímax, e o pseudônimo escolhido realça tal situação.

${ }^{7}$ Edificante, na concepção kierkegaardiana, "é tudo aquilo que pode ajudar um indivíduo, dentro da sua interiorização, a apropriar-se de valores éticos ou religiosos" (PAULA, 2007, p. 63).

${ }^{8}$ Filisteu - no sentido não-histórico, refere-se à pessoa deficiente na cultura das Artes Liberais, um oponente intolerante do boêmio que exibe um código moral restritivo, desaprecia as idéias artísticas. A partir do século XIX, na Europa, a palavra filisteu passou a designar pessoas de comportamento acovardado, que têm ojeriza a questões políticas maiores, não valorizam a arte, a beleza ou o conteúdo intelectual e satisfazem-se com o cotidiano da vida privada pacata e confortável. O filisteu não seria adepto de ideais, mas apenas de propostas práticas passíveis de serem contabilizadas em melhorias para sua vida privada imediata.

${ }^{9}$ Mateus 06: 24-34. (PAULA, 2007, p. 65). 